\title{
Penerapan Pendidikan Karakter Pada Mata Kuliah Atletik Dasar
}

\author{
Tjung Hauw Sin \\ Universitas Negeri Padang
}

\begin{abstract}
Abtract
Degradasi karakter saat ini menjadi masalah yang begitu penting di perguruan tinggi. Hal ini dikarenakan setiap tahunnya terjadi kemundaran moral terutama bagi mahasiswa tahun pertama. Karakter atau moral mahasiswa tahun pertama ini biasanya bawaan dari sekolah asal. Untuk itu dosen di perguruan tinggi perlu memikirkan suatu cara atau inovasi, yang dimana tujuannya untuk meningkatkan nilai-nilai karakter dikalangan mahasiswa. Tujuan dari penelitian ini adalah sebagai evaluasi pembelajaran mengenai karakter mahasiswa tahun pertama di jurusan Kepelatihan Olahraga. Jenis penelitin merupakan penelitian kualitatif yang diuraikan dalam bentuk deskriptif. Penelitian dilaksanakan pada tanggal 1 Maret - 30 April 2019. Penelitian dilaksanakan di Fakultas Ilmu Keolahragaan Universitas Negeri Padang. Proses pengumpulan data dalam penelitian lebih banyak bersifat uraian dari hasil observasi, wawancara, diskusi dan dokumentasi. Hasil penelitian menunjukan bahwa penerapan pendidikan karakter perlu ditingkatkan didalam proses belajar mengajar di Perguruan Tinggi hal ini sebagai upaya meningkatkan moral mahasiswa. Pentingnya penerapan pendidikan karakter di Perguruan Tinggi bertujuan mendorong kebiasaan dan mahasiswa memiliki ahlak maupun prilkau yang terpuji dan sejalan dengan nilai-nilai universal dan tradisi budaya bangsa yang religious.
\end{abstract}

Keywords: pendidikan karakter, atletik dasar

This is an open access article distributed under the Creative Commons Attribution License, which permits unrestricted use,
distribution, and reproduction in any medium, provided the original work is properly cited. (C2019 by author

\section{PENDAHULUAN}

Pendidikan karakter merupakan upaya yang dirancang dan dilaksanakan secara sistematis untuk membantu peserta didik memahami nilai-nilai perilaku manusia yang berhubungan dengan Tuhan Yang Maha Esa, diri sendiri, sesama manusia, lingkungan, dan kebangsaan yang terwujud dalam pikiran, sikap, perasaan, perkataan, dan perbuatan berdasarkan normanorma agama, hukum, tata krama, budaya, dan adat istiadat (Dwiyanto Joko Pranowo, 2013). Menurut Lickona (2008) mengatakan bahwa pendidikan karakter adalah upaya mengembangkan kebajikan sebagai fondasi dari kehidupan yang berguna, bermakna, produktif dan fondasi untuk masyarakat yang adil, penuh belas kasih dan maju.

Pendidikan merupakan salah satu pilar yang ikut menopang berdirinya sebuah peradaban yang disebut dengan Bangsa (Susanti, 2013). Eksistensi suatu bangsa sangat ditentukan oleh karakter yang dimilikinya. Pendidikan karakter menjadi kunci terpenting kebangkitan Bangsa Indonesia dari keterpurukan, untuk menyongsong datangnya peradaban baru (Susanti, Sukestiyarno, Sugiharti, 2013). Bangsa yang memiliki karakter kuat dapat menjadi bangsa yang bermartabat dan disegani oleh bangsa lain di seluruh dunia.

Pentingnya pendidikan karakter yang harus diintegrasikan ke dalam kurikulum di sekolah dan di perguruan tinggi dilatarbelakangi oleh adanya realitas permasalahan kebangsaan yang berkembang saat ini. Pendidikan karakter dimaksudkan untuk mengembangkan kemampuan dan membentuk watak serta peradaban bangsa yang bermartabat dalam rangka mencerdaskan kehidupan bangsa (Triyono, 2012). 
Adapun nilai dan deskripsi nilai pendidikan karakter pada tabel menurut Judiani (2010), antara lain sebagai berikut:

\begin{tabular}{lll}
\hline No & Nilai & Deskripsi \\
\hline $\mathbf{1}$ & Religius & $\begin{array}{l}\text { Sikap dan perilaku yang patuh dalam melaksanakan ajaran } \\
\text { agama yang dianutnya, toleran terhadap pelaksanaan ibadah } \\
\text { agama lain, dan hidup rukun dengan pemeluk agama lain }\end{array}$ \\
$\mathbf{2}$ & Jujur & $\begin{array}{l}\text { Perilaku yang didasarkan pada upaya menjadikan dirinya } \\
\text { sebagai orang yang selalu dapat dipercaya dalam perkataan, } \\
\text { tindakan, dan pekerjaan. }\end{array}$
\end{tabular}

$\begin{array}{lll}3 & \text { Toleransi } & \begin{array}{l}\text { Sikap dan tindakan yang menghargai perbedaan agama, suku, } \\ \text { etnis, pendapat, sikap, dan tindakan orang lain yang berbeda dari } \\ \text { dirinya. }\end{array} \\ 4 \text { Disiplin } & \begin{array}{l}\text { Tindakan yang menunjukkan perilaku tertib dan patuh pada } \\ \text { berbagai ketentuan dan peraturan. }\end{array}\end{array}$

$\begin{array}{lll}5 & \text { Kerja Keras } & \begin{array}{l}\text { Perilaku yang menunjukkan upaya sungguh-sungguh dalam } \\ \text { mengatasi berbagai hambatan belajar dan tugas, serta } \\ \text { menyelesaikan tugas dengan sebaik-baiknya. }\end{array} \\ \mathbf{6} & \text { Kreatif } & \begin{array}{l}\text { Berpikir dan melakukan sesuatu untuk menghasilkan cara atau } \\ \text { hasil baru dari sesuatu yang telah dimiliki. }\end{array} \\ \mathbf{7} & \text { Mandiri } & \begin{array}{l}\text { Sikap dan perilaku yang tidak mudah tergantung pada orang lain } \\ \text { dalam menyelesaikan tugas-tugas. }\end{array} \\ & \text { Demokratis } & \begin{array}{l}\text { Cara berfikir, bersikap, dan bertindak yang menilai sama hak } \\ \text { dan kewajiban dirinya dan orang lain. }\end{array}\end{array}$

$\begin{array}{lll}9 \text { Rasa Ingin Tahu } & \begin{array}{l}\text { Sikap dan tindakan yang selalu berupaya untuk mengetahui } \\ \text { lebih mendalam dan meluas dari sesuatu yang dipelajarinya, } \\ \text { dilihat, dan didengar. }\end{array} \\ \mathbf{1 0} \text { Semangat Kebangsaan } & \begin{array}{l}\text { Cara berpikir, bertindak, dan berwawasan yang menempatkan } \\ \text { kepentingan bangsa dan negaradi atas kepentingan diri dan } \\ \text { kelompoknya. }\end{array}\end{array}$

11 Cinta Tanah Air $\quad \begin{aligned} & \text { Cara berfikir, bersikap, dan berbuat yang menunjukkan } \\ & \text { kesetiaan, kepedulian, dan penghargaan yang tinggi terhadap } \\ & \text { bahasa, lingkungan fisik, sosial, budaya, ekonomi, dan politik } \\ & \text { bangsa. }\end{aligned}$

\begin{tabular}{lll}
13 & Bersahabat/Komunikatif & $\begin{array}{l}\text { Tindakan yang memperlihatkan rasa senang berbicara, bergaul, } \\
\text { dan bekerja sama dengan orang lain. }\end{array}$ \\
$\mathbf{1 4}$ & Cinta Damai & $\begin{array}{l}\text { Sikap, perkataan, dan tindakan yang menyebabkan orang lain } \\
\text { merasa senang dan aman atas kehadiran dirinya. }\end{array}$ \\
$\mathbf{1 5}$ & Gemar Membaca & $\begin{array}{l}\text { Kebiasaan menyediakan waktu untuk membaca berbagai bacaan } \\
\text { yang memberikan kebajikan bagi dirinya. }\end{array}$ \\
& Peduli Lingkungan & Lingkungan alam di sekitarnya, dan mengembangkan upaya- \\
\hline
\end{tabular}


upaya untuk memperbaiki kerusakan alam yang sudah terjadi.

\begin{tabular}{|c|c|c|}
\hline 17 & Peduli Sosial & $\begin{array}{l}\text { Sikap dan tindakan yang selalu ingin memberi bantuan pada } \\
\text { orang lain dan masyarakat yang membutuhkan. }\end{array}$ \\
\hline 18 & Tanggung-jawab & $\begin{array}{l}\text { Sikap dan perilaku seseorang untuk melaksanakan tugas dan } \\
\text { kewajibannya, yang seharusnya dia lakukan, terhadap diri } \\
\text { sendiri, masyarakat, lingkungan (alam, sosial dan budaya), } \\
\text { negara dan Tuhan Yang Maha Esa. }\end{array}$ \\
\hline
\end{tabular}

Perguruan tinggi merupakan lembaga akademik dengan tugas utamanya menyelenggarakan pendidikan dan mengembangkan ilmu pengetahuan, teknologi dan seni (Rukiyati, Sutarini, dan Priyoyuwono, 2014). Penting bagi perguruan tinggi untuk tidak hanya memperhatikan kebutuhan kompetensi akademis mahasiswa, tapi juga pembinaan karakternya agar lulusan menjadi lulusan yang siap secara akademis dan berkarakter baik (Chrisiana, 2005). Penyelenggaraan pendidikan mencakup upaya pembentukan kepribadian mahasiswa sehingga menjadi orang yang cerdas sekaligus berkarakter baik.

Untuk memanajemen pendidikan karakter pada mahasiswa hendaknya memperhatikan perkembangan budaya dan teknologi yang ada (Raharjo, Rifai, Suminar, 2015). Kemajuan teknologi dan informasi yang sangat cepat dan mengglobal dirasakan dapat mengubah peradaban umat manusia. Perubahan dalam pola pikir dan karakter mahasiswa juga ikut menyesuaikan, sehingga apa yang dianggap baik pada masa lalu belum tentu sesuai dengan keadaan masa kini (Situmorang, 2013). Perubahan ini juga membawa dampak terhadap karakter mahasiswa yang ditunjukkan dari ditemukannya beberapa kasus pergeseran perilaku dan moral mahasiswa yang tidak sesuai dengan budaya lokal Indonesia. Nilai-nilai universal seperti kejujuran, tanggungjawab, keteladanan, rasa memiliki, saling mengasihi, penghormatan terhadap sesama, dan pengakuan terhadap hak orang lain tidak lagi menjadi milik semua masyarakat, termasuk mahasiswa di perguruan tinggi.

Pendidikan karakter dalam konteks pendidikan di Indonesia adalah pendidikan nilai, yakni pendidikan nilai-nilai luhur yang bersumber dari budaya bangsa Indonesia sendiri, dalam rangka membina kepribadian generasi muda (Julaiha, 2014). Pendidikan karakter ini pun diharapkan mampu menjadi pondasi utama dalam mensukseskan Indonesia Emas 2025. Di perguruan tinggi, pendidikan karakter mendapatkan perhatian yang cukup besar, hal ini dikarenakan permasalahan karakter menjadi masalah yang urgen untuk diselesaikan (Baroroh, 2011). Permasalahan ini juga merupakan tanggung jawab pendidik (guru/dosen).

Mahasiswa sebagai agent of social change (agen perubahan sosial) dan selaku insan akademis dipandang memiliki kekuatan intelektual yang lebih sehingga kepekaan dan nalar yang rasional diharapkan dapat memberikan kontribusi nyata terhadap pembangunan pendidikan dan sosial dimasyarakat (Buchori, Ibrahim \& Saman, 2016). Oleh karena itu sudah menjadi konsekuensi terhadap tuntutan dari seorang mahasiswa untuk mampu mengoptimalkan potensi yang dimilikinya sebagai suatu kebutuhan individual maupun kelompok (Widia, 2014).

Pembangunan karakter melalui pendidikan di antaranya pengintegrasian nilainilai karakter oleh unit MKU (Mata Kuliah Umum) dan dilanjutkan dengan pengintegrasian pendidikan karakter sejak perkuliahan tahun 2010 (Winarni, 2013). Pembentukan karakter tersebut harus dilakukan dengan komitmen dan kerja keras bersama antara peserta didik, guru, dosen dan semua stake holders pendidikan untuk mencerdaskan dan mewujudkan cita-cita bangsa dan negara Indonesia tercinta (Putri, 2011). Pentingnya karakter untuk membangun SDM yang berkualitas, maka pendidikan karakter perlu dilakukan dengan tepat, sehingga pembentukan karakter merupakan sesuatu yang tidak dapat dipisahkan dari kehidupan. Pendidikan karakter juga harus menyertai semua aspek kehidupan termasuk dilembaga pendidikan.

Marten (2004) mengusulkan strategi pembelajaran karakter yang efektif, yakni harus dilakukan secara lebih konkret. Ada tiga tahapan yang perlu dilakukan dalam pembelajaran karakter, yakni: identifikasi nilai, pembelajaran nilai, dan memberikan kesempatan untuk menerapkan nilai tersebut. Mahasiswa tetap harus diberikan pendidikan karakter agar terbentuk mahasiswa yang unggul dan berwatak positif (Nawangsari, 2011) atau mahasiswa berkarakter luhur (Handoyo \& Tijan, 2011). Hakikat dari pendidikan karakter dalam konteks pendidikan di Indonesia adalah pedidikan nilai, yakni pendidikan nilai-nilai luhur yang bersumber dari budaya bangsa Indonesia sendiri, dalam rangka membina kepribadian generasi muda (Walid, 2011). 
Para penggiat pendidikan karakter terkadang sering mengabaikan alasan keterbatasan visi pimpinan perguruan tinggi tersebut, sehingga selalu berlawanan dengan tujuan utama universitas. Di sisi lain, antusiasme para penggiat pendidikan karakter dan pimpinan perguruan tinggi tersebut juga mengabaikan kesempatan untuk mendiskusikan tentang keyakinan pentingnya pendidikan karakter. Padahal dengan memulai adanya prakarsa dialog semacam itu dalam komunitas akademik yang demokratis, penuh dengan saling pengertian, konsensus, maka perubahan jangka panjang dapat dicapai. Langkah ini merupakan cara terbaik untuk memastikan bahwa pendidikan karakter dapat dilakukan dengan cara-cara yang lebih efektive dan mendalam.

Degradasi karakter saat ini memjadi masalah yang begitu penting di perguruan tinggi. Hal ini dikarenakan setiap tahunnya terjadi kemundaran moral terutama bagi mahasiswa tahun pertama. Karakter atau moral mahasiswa tahun pertama ini biasanya bawaan dari sekolah asal. Untuk itu dosen di perguruan tinggi perlu memikirkan suatu cara atau inovasi, yang dimana tujuannya untuk meningkatkan nilai-nilai karakter dikalangan mahasiswa. Konsep pembelajaran dikelas tidak hanya fokus kepada pegetahuan saja akan tetapi juga fokus kearah penerapan nilai-nilai karakter.

Berdasarkan penjabaran masalah di atas peneliti berusaha memgimplementasikan nilai karakter kerja keras, kerjasama team, disiplin dan kreatif melalui proses pembuatan vidio pembelajaran. Dimana para mahasiswa diberikan tugas membuat vidio pembelajaran berdasarkan kelompok yang telah mereka tentukan. Dari proses pembuatan vidio pembelajaran tersebut peneliti akan mendeskripsikan bagaimana penerapan nilai karakter mandiri, bersahabat/komunikatif dan tanggungjawab dimiliki mahasiswa. Pemberian tugas akhir semester menggunakan pendekatan teknologi dianggap effective dalam menilai karakter mahasiswa dalam kemandirian, bersahabat/komunikatif dan tanggungjawab. Selain itu pembuatan vidio pembelajran didalam perkulihan juga berguna sebagai bahan evaluasi mengenai materi perkulihan yang sebelumnya telah dijelaskan dan juga sebagai evaluasi gerak didalam mata kuliah atletik dasar.

Tujuan dari penelitian ini adalah sebagai evaluasi karakter mahasiswa khususnya mahasiswa tahun pertama mengenai karakter yang masuk kedalam ranah penilaian afektif. Penilaian afektif merupakan salah satu aspek penilaian diranah sikap atau etika mahasiswa didalam proses perkulihan. Mahasiswa olahraga yang mengandalkan prinsip sportivitas perlu memiliki nilai afektif yang baik, salah satunya dengan penerapan nilainilai karakter pada setiap proses pembelajaran di perkuliahan.

\section{METODE}

Penelitian dilaksanakan pada tanggal 1 Maret - 30 April 2019. Penelitian dilaksanakan di Fakultas Ilmu Keolahragaan Universitas Negeri Padang. Proses pengumpulan data dalam penelitian lebih banyak bersifat uraian dari hasil observasi, wawancara, diskusi dan dokumentasi. Instrument dalam penelitian ini berupa pemberian tugas pembuatan vidio pembelajaran gerak atletik, dimana peneliti nantinya akan memgamati proses pembuatan vidio tersebut berdasarkan nilai karakter mandiri, bersahabat/komunikatif dan tanggungjawab. Data yang telah diperoleh akan dianalisis secara kualitatif serta diuraikan dalam bentuk deskriptif (Patton, 2002:103). Teknik analisis data yang digunakan dalam penelitian ini adalah menggunakan langkah-langkah seperti yang dikemukakan oleh Bungin (2003:70), yaitu sebagai berikut:

a. Pengumpulan data (data collection)

b. Reduksi data (data reduction)

c. Display data

d. Verifikasi dan penegasan kesimpulan (conclution drawing and verification)

e. Triangulasi

Adapun subjek dalam penelitian berjumlah 60 orang mahasiswa semester 2 dikelas atletik dasar. 60 orang mahasiswa tersebut berasal dari daerah yang berbeda, selain itu peneliti juga mengunakan kategori usia dan jenis kelamin yang berbeda. Hal ini bertujuan untuk memperoleh informasi yang beragam dari sumber yang memiliki ketentuan yang berbeda.

\section{HASIL PENELITIAN}

Temuan penelitian merupakan rangkuman mengenai data dari hasil wawancara dan diskusi kepada pihak-pihak yang ada dalam proses pembuatan vidio pembelajran. Temuan penelitian mengenai penerapan ilainilai karakter pada mata kuliah atletik dasar akan dijelaskan secara umum dan nyata (real) sebagai hasil penelitian. Pembahasan secara umum dalam arti peneliti tidak mendeskripsikan masing masing subjek melainkan mendeskripsikan hasil temuan secara sistematis berdasarkan tema-tema yang ditemukan dalam penelitian atau fokus penelitian yang menyatakan pernyataan-pernyataan subjek penelitian. 
Berdasarkan hasil wawancara dan dokumentasi dalam penelitian ini peneliti mengali lebih dalam mengenai penerapan nilai-nilai karakter terhadap mahasiswa tahun pertama pada mata kuliah atletik dasar melalui sifat mandiri, komunikatif/ bersahabat dan tanggungjawab. Informan yang terlibat dalam wawancara merupakan mahasiswa tahun pertama jurusan Kepelatihan di Universitas Negeri Padang. Untuk mengetahui sifat mandiri, komunikatif/ bersahabat dan tanggungjawab. peneliti memperoleh data berdasarkan proses pembuatan vidio pembelajan pada mata kuliah atletik dasar. Adapun deskripsi mengenai hasil penelitian yang dilakukan oleh peneliti antara lain sebagai berikut:

Temuan peneliti menunjukkan bahwa karakter mandiri yang dimiliki mahasiswa tahun pertama belum cukup baik. Hal ini terlihat dari tindakan mahasiswa yang selalu dikontrol atau diawasi oleh dosen maupun asissten dosen mata kuliah atletik. Kemandiran mahasiswa tahun pertama memang sedikit berbeda dengan mahasiswa senior hal ini dikarenakan adanya sifat bawaan dari sekolah asal yang masih selalu di bantu maupun di awasi oleh guru di sekolah mereka berasal.

Rendahnya kemandiran mahasiswa dalam proses pembuatan vidio pembelajaran sebagai tugas akhir perkulihan dinilai lambat dan kurang optimal hal ini disebabkan mahasiswa masih memerlukan mentor maupun pembimbing didalam proses pembuatan vidio pembelajaran tersebut. Padahal mahasiswa telah dibekali kemampuan gerak-gerak dasar atletik secara berulang kali, akan tetapi mahasiswa masih belum cukup memahami konsep gerak-gerak dasar atletik yang akan diterapkan di vidio pembelajaran mereka.

Temuan lain yang diperoleh peneliti, bahwa tidak semua mahasiswa memiliki sifat kemandiran yang rendah. Ada beberapa kelompok mahasiswa yang peneliti nilai cukup baik dalam penyelesaian vidio pembelajaran yang dibuat sebagai tugas akhir perkulihan. Beberapa mahasiswa ini cukup kompeten dalam setiap bagian perekaman gerak-gerak dasar atletik. Beberapa kelompok menggunakan bantuan media social seperti youtube sebagai panduan melakukan gerakan yang benar.

Temuan peneliti menunjukkan bahwa nilai karakter komunikatif/ bersahabat dalam proses pembuatan vidio pembelajaran sangat baik. Hal ini dapat dibuktikan berdasarkan pembagian tugas dalam proses penbuatan vidio pembelajaran yang cukup adil. Dimana setiap kelompok saling melengkapi kekurangan satu sama lain. Apabila ada salah satu anggota kelompok yang tidak menguasai gerak-gerak dasar atletik maka salah satu anggota kelompok tersebut bertugas sebagai perekam vidio dengan demikian dapat diketahui bahwa komunikasi antar mahasiswa cukup baik dalam menciptakan kerja sama team yang maksimal.

Komunikasi antar mahasiswa juga cukup baik sehingga tidak ada sikap saling menyalahkan antar mahasiswa apabila terjadi suatu kesalahan dalam proses pembuatan vidio. Komunikasi yang baik ini juga dapat terlihat dari sikap saling bertanya satu sama lain mengenai materi gerakan yang kurang dipahami.

Temuan peneliti menunjukkan bahwa karakter tanggung jawab mahasiswa selama proses pembuatan vidio pembelajaran sangat baik. hal ini dapat terlihat dari antusiasme mahaisiswa dalam proses penyelesain perekaman gerakan-gerakan atletik dasar. Tanggungjawab mahasiswa dalam penyelesaian tugas vidio pembelajaran merupakan suatu bentuk tugas akhir yang harus diselesaikan dengan baik agar nantinya mahasiswa juga memperoleh hasil yang baik pula berupa nilai akhir semester yang memuaskan.

Penerapan pendidikan karakter dalam pendidikan erat kaitannya dengan perkembangan mahasiswa (Prastyo, 2012). Pentingnya penerapan pendidikan karakter di Perguruan Tinggi bertujuan mendorong kebiasaan dan mahasiswa memiliki akhlak maupun prilkau yang terpuji dan sejalan dengan nilai-nilai universal dan tradisi budaya bangsa yang religius, menanamkan jiwa kepemimpinan dan tanggung jawab, mahasiswa sebagai penerus bangsa, memupuk ketegaran dan kepekaan mental mahasiswa terhadap situasi sekitarnya sehingga tidak terjerumus ke dalam perilaku yang menyimpang, baik secara individual maupun sosial. Meningkatkan kemampuan untuk menghindari sifat-sifat tercela yang dapat merusak diri sendiri, orang lain dan lingkungan.

Dalam membangun generasi cerdas, disiplin dan berkarakter dimulai dari pendidikan yang berkualitas dan para pengajar yang profesinal dalam mengajar. Penerapan nilai-nilai pendidikan karakter harus di terapkan pada setiap institusi pendidikan dan individu agar nantinya setiap mahasiswa memiliki salah satunya rasa tanggung jawab yang besar sebagi seorang mahasiswa. Universitas Negeri Padang (UNP) sebagai Character Building University berkomitmen membangun pendidikan karakter, yang dilakukan dari berbagai aspek, termasuk diantaranya melalui integrasi pendidikan karakter melalui pembelajaran. Alizamar (2019) karakter cerdas membuat sifat pribadi seseorang menjadi lebih stabil sehingga dapat dikembangkan melalui infusi dalam pendidikan.

Bagi mahasiswa, pendidikan karakter cerdas guna ntuk menghasilkan calon pemimpin bangsa yang tidak hanya mampu di bidang akademik, namun juga terpuji (Wardono, Kurniasih, 2015). Salah satu nilai karakter yang harus diterapkan ke mahasiswa dalam proses pembelajaran adalah nilai kemandirian. Pendidikan karakter mandiri bertujuan untuk insan-insan yang percaya kepada dirinya sendiri dalam mengerjakan sesuatu 
urusan. Karakter mandiri mendorong dan memacu seseorang untuk memecahkan sendiri persoalan hidup dan kehidupannya, sehingga mahasiswa termotivasi untuk berinisiatif, berkreasi, berinovasi, proaktif dan bekerja keras. Nilai karakter mandiri memacu keberanian mahasiswa untuk berbuat atau bereaksi, tidak pasrah dan beku, tetap dinamis, energik dan selalu optimis menuju ke masa depan. Pendidikan karakter cerdas dilakukan dengan terintegrias sesuai dengan pembelajaran proses (Ridlo \& Irsadi, 2012).

Nilai-nilai karakter cerdas yang dimiliki mahasiswa memberikan stimulasi bagi perkembangannya untuk berpikiran lebih maju (Umari, 2018). Seseorang mahasiswa yang berkarakter mandiri, setelah menyelesaikan kuliah (tamat) mahasiswa akan menggunakan ilmunya untuk menciptakan sesuatu inovasi yang baru yang akan mempermudahan kehidupan disekitarnya. Contohnya lulusan Perguruan tinggi yang memiliki kemandirian akan berupaya menciptakan lapangan pekerjaan bagi orang lain tanpa tergantung dengan pekerjaan yang ada di Pemerintahan. Nilai mandiri menjadikan seorang mahasiswa memiliki sifat kreative dan selalu berpikir bagaimana menciptkan kemudahan bagi dirinya maupun untuk orang lain. Pendidikan karakter cerdas akan membantu mahasiswa dalam membentuk dirinya sesuai dengan nilai-nilai yang ada di dalam pancasila (Octavia \& Ubei, 2017).

Guru atau dosen selalu dianggap sebagai sumber ilmu. Sehingga mahasiswa seringkali hanya menerima dan mendengarkan ilmu yang diberikan oleh dosen. Mahasiswa cenderung kurang aktif dalam belajar maupun mencari sumber-sumber pendukung ilmu yang dipelajarinya. Untuk itu, kemandirian mahasiswa dalam belajar perlu ditingkatkan. sehingga perlu ada upaya untuk mendorong kemandirian mahasiswa dalam belajar. Kemandirian mahasiswa itu terkait dengan keaktifan mahasiswa dalam menunjang proses pembelajaran itu sendiri. Misalnya dengan melakukan inisiatif untuk mengerjakan tugas-tugas selain yang telah diajarkan di kelas (Renata \&Kristiawan \& Pratami, 2017).

Dalam beroganisasi atau melalui kegiatan mahasiswa dapat membangun karakter cerdas bagi pribadi masing-masing mahasiswa (Sofyan, 2011). Bersahabat atau komunikatif merupakan tindakan yang memperlihatkan rasa senang berbicara, bergaul, dan bekerja sama dengan orang lain. Bersahabat atau komunikasi yang baik antar mahasiswa akan melahirkan sikap toleransi maupun kerjasama team yang baik. Bersahabat atau komunikatif sebagai bagian dari nilai karakter perlu ditingkatkan dengan cara sering memberikan tugas perkelompok atau team sebagai upaya peningkatan sosial antar mahasiswa. Dengan sering melakukan tugas kelompok mahasiswa akan terbiasa untuk berkeja sama dalam menyelesaikan masalah. Tanis (2013) pentingnya pendididikan membantu mahasiswa dalam membentuk kepribadian sehingga mampu menyesuaikan diri dengan lingkungan di manapun ia berada.

Jurusan Kepelatihan Olahraga di Universitas Negeri Padang merupakan salah satu jurusan yang berupaya menerapkan niali bersahabat atau komunikatif didalam proses pembelajran. Bersahabat atau komunikatif yang baik antar mahasiswa akan memimbulkan harmonisasi dalam proses belajar mengajar di perkulihan. Mahasiswa akan saling bertukar pola pikir sebagai upaya memperoleh informasi yang baru antar mahasiswa. Dengan demikian sikap bullying maupun tawuran akan terminimalisir dengan adanya bersahabat atau komunikasi yang baik antar sesame mahasiswa.

Tanggung jawab merupakan sikap dan perilaku seseorang untuk melaksanakan tugas dan kewajibannya, yang seharusnya dia lakukan, terhadap diri sendiri, masyarakat, lingkungan (alam, sosial dan budaya), negara dan Tuhan Yang Maha Esa. Di Perguruan Tinggi mahasiswa memiliki tanggungjawab untuk menyelesaikan perkulihan dengan sebaik mungkin. Adapun kesuksesaan bagi mahasiswa itu sendiri adalah ketika mahasiswa memyelesiakan perkulihan dengan waktu cepat serta memiliki IPK yang memuaskan, dengan demikian tanggungjawabnya sebagai mahasiswa telah berjalan dengan baik.

Lulusan perguruan tinggi yang berkualitas merupakan para lulusan yang akan bertanggungjawab pada setiap tugas yang diberikan kepadanya. Pentingnya penerapan nilai karakter tanggungjawab didalam proses belajar mengajar sebagai upaya meningkatkan mutu mahasiswa yang akan berguna bagi masyarakat luas. Tanggungjawab sebagai sesuatu yang amat penting bagi seorang lulusan mahasiswa dalam memperoleh pekerjaan dikarenakan nilai tanggungjawab merupakan suatu bentuk kepercayaan yang harus diselesaikan dengan baik. Seorang mahasiswa harus memiliki tanggungjawab baik penyelesain tugas kuliah maupun tanggungjawab lainnya.

\section{KESIMPULAN}

Penerapan pendidikan karakter di Perguruan Tinggi sebagai upaya menciptakan generasi yang unggul tidak hanya di akademis tapi juga moral yang baik. Perguruan Tinggi sebagai salah satu wadah bagi para sarjana perlu menetapkan pendidikan karakter sebagai salah satu aspek peningkatkan nilai moral mahasiswa yang harus diterapkan disetiap proses pembelajaran di perkulihan. Pentingnya penerapan pendidikan karakter di Perguruan Tinggi bertujuan mendorong kebiasaan dan mahasiswa memiliki ahlak maupun perilaku yang terpuji dan sejalan dengan nilai-nilai universal dan tradisi budaya bangsa yang religius, menanamkan jiwa kepemimpinan dan tanggung jawab, mahasiswa sebagai penerus bangsa, memupuk ketegaran dan kepekaan mental mahasiswa terhadap situasi sekitarnya sehingga tidak terjerumus ke dalam perilaku yang menyimpang, baik secara 
individual maupun sosial. Meningkatkan kemampuan untuk menghindari sifat-sifat tercela yang dapat merusak diri sendiri, orang lain dan lingkungan.

Dalam proses pembelajaran yang berkualitas perlu adanya evaluasi pembelajaran terutama proses pembelajaran dalam ranah afektif. Dosen sebagai tenaga pengajar di perguruan tinggi mesti mengkombinasikan model pengajaran karakter sebagai salah satu cara dalam meningkatkan karakter mahsiswa khususnya mahasiswa tahun pertama.

\section{DAFTAR RUJUKAN}

Alizamar. (2019). Pengembangan Karakter Cerdas Mahasiswa melalui Infusi dalam Pembelajaran. International Counseling Seminar 2015, Padang, 13-14 Maret 2015. Universitas Negeri Padang.

Baroroh, Kiromim. (2011). Upaya Meningkatkan Nilai-Nilai Karakter Peserta Didik Melalui Penerapan Metode Role Playing. Yogyakarta: Universitas Negeri Yogyakarta Jurnal Ekonomi \& Pendidikan, Volume 8 Nomor 2, November 2011

Bungin, Burhan. (2003). Analisis Data Penelitian Kualitatif. Jakarta: Raja Grafindo Persada.

Chrisiana, Wanda. (2005). UPAYA PENERAPAN PENDIDIKAN KARAKTER BAGI MAHASISWA (Studi Kasus di Jurusan Teknik Industri UK Petra). Jurnal Teknik Industri:Jurnal Keilmuan dan Aplikasi Teknik Industri. 7(1), https://doi.org/10.9744/jti.7.1.pp.\%2083-90

Handoyo \& Tijan. (2011). Model Pendidikan Karakter Berbasis Konservasi Pengalaman Universitas Negeri Semarang. Jakarta: Direktorat Ketenagaan, Direktorat Jenderal Pendidikan Tinggi, Kementerian Pendidikan Nasional.

Judiani, Sri. (2010). Implementasi Pendidikan Karakter di Sekolah Dasar Melalui Penguatan Pelaksanaan Kurikulum. Setditjen Manajemen Pendidikan Dasar dan Menengah, Kemendiknas Jurnal Pendidikan dan Kebudayaan, Vol. 16, Edisi Khusus III, Oktober 2010

Julaiha, Siti. (2014). Implementasi Pendidikan Karakter Dalam Pembelajaran. Samarinda: STAIN Samarinda Dinamika Ilmu Vol. 14. No 2, Desember 2014

Lickona, Thomas. (2008). Effective Character Education. Diakses pada tanggal 24 April 2019 dari www.cortland.- edu/character/articles/char_v.asp.

Marten, R. (2004). Successful Coaching (Edisi Ketiga). Champaign, IL: Human Kinetics.

Nawangsari, E. (2011). Relevansi Pendidikan Karakter pada Sistem Belajar Mengajar Mahasiswa. E-Journal STIE AUB Surakarta.

Octavia, Erna \& Rubei, M. Anwar. (2017). Pendidikan Karakter berbasis Pancasila untuk Membentuk Mahasiswa Prodi PPKN Menjadi Warga Negara yang Baik dan Cerdas. Sosial Horizon: Jurnal Pendidikan Sosial. DOI: http://dx.doi.org/10.31571/sosial.v4i1.427

Patton, M.Q. (2002). Qualitative Research and Evaluation Methods ( $3^{\text {rd }}$ ed.). Thousand Oaks, CA:Sage Publications, Inc.

Pranowo, Dwiyanto Joko. (2013). Implementasi Pendidikan Karakter Kepedulian Dan Kerja Sama Pada Mata Kuliah Keterampilan Berbicara Bahasa Prancis Dengan Metode Bermain Peran. Yogyakarta: Universitas Negeri Yogyakarta Jurnal Pendidikan Karakter, Tahun III, Nomor 2, Juni 2013

Prastyo, Angga Teguh. (2012). Merancang Perencaan Pembelajaran Berbasis Pendidikan Karakter. Jurnal ElHikmah. 9(2).

Putri, Noviani Achmad. (2011). Penanaman Nilai-Nilai Pendidikan Karakter Melalui Mata Pelajaran Sosiologi. Semarang: Universitas Negeri Semarang JURNAL KOMUNITAS ISSN: 2086-5465 http://journal.unnes.ac.id/sju/index.php/ujme 
Raharjo, Tri Joko ., \& Rifai, Achmad., \& Suminar, Tri. (2015). Keefektivan Manajemen Pendidikan Karakter Pilar Konservasi Budaya melalui Strategi Pembelajaran Inkuiri Sosial Bagi Mahasiswa Jurusan Pendidikan Luar Sekolah Fakultas Ilmu Pendidikan Universitas Negeri Semarang. Journal of Nonformal Education. 1 (1).

Renata., \& Kristiawan, Muhammad., \& Pratami, Fatmi Andi Rizki. (2017). Perbincangan Pendidikan Karakter. Prosiding Seminar Nas/ional Program Pascasarjana Universitas PGRI Palembang.

Ridlo, Saiful \& Irsasi, Andin. (2012). Pengembangan Nilai Karakter Konservasi Berbasis Pembelajaran. Jurnal Penelitian Pendidikan. Universitas Negeri Semarang. 29 (2).

Rukiyati., \& Sutarini, Nany., \& Priyoyuwono. (2014). Penanaman Nilai Karakter Tanggung Jawab Dan Kerja Sama Terintegrasi Dalam Perkuliahan Ilmu Pendidikan. Yogyakarta: Universitas Negeri Yogyakarta Jurnal Pendidikan Karakter, Tahun IV, Nomor 2, Juni 2014.

Situmorang, Manihar. (2013). Pengembangan Buku Ajar Kimia SMA Melalui Inovasi Pembelajaran Dan Integrasi Pendidikan Karakter Untuk Meningkatkan Hasil Belajar Siswa. Medan: Universitas Negeri Medan Prosiding Semirata FMIPA Universitas Lampung, 2013

Sofyan, Herminarto. (2011). Implementasi Pendidikan Karakter Cerdas Melalui Kegiatan Kemahasiswaan. Artikel dalam BUKU Pendidikan Karakter. Universitas Negeri Yogyakarta.

Susanti, Eka Lia., \& Sukestiyarno, YL., \& Sugiharti, Endang. (2013). Efektivitas Pembelajaran Matematika Dengan Metode Problem Posing Berbasis Pendidikan Karakter. Semarang: Universitas Negeri Semarang Unnes Journal of Mathematics Education ISSN: 2252-6927 http://journal.unnes.ac.id/sju/index.php/ujme

Susanti, Rosa. (2013). Penerapan Pendidikan Karakter Di Kalangan Mahasiswa. Payakumbuh: STKIP Abdi Pendidikan Payakumbuh Jurnal Al-Ta'lim, Jilid 1, Nomor 6 November 2013, hlm. 480-487

Tanis, Hibur. (2013). Pentingnya Pendidikan Character Building dalam Membentuk Kepribadian Mahasiswa. Humaniora: Journal Binus. 4 (2).

Triyono, Sulis. (2012). Pengintegrasian Pendidikan Karakter Dalam Pembelajaran Bahasa Jerman. Yogyakarta: Universitas Negeri Yogyakarta Jurnal Pendidikan Karakter, Tahun II, Nomor 3, Oktober 2012

Umari, T. (2018). Analisis Nilai-nilai Karakter Cerdas Mahasiswa FKIP Universitas Riau Pekanbaru. Educhild. Ejournal Universitas Riau.

Walid, M. (2011). Model Pendidikan Karakter di Perguruan Tinggi Agama Islam (Studi tentang Pendidikan Karakter Berbasis Ulul albab di Universitas Islam Negeri Maulana Malik Ibrahim Malang). Jurnal eL-QUDWAH - Vol 1 No 5, ed April 2011. p.115-15.

Wardono., \& Kurniasih, Ary Woro. (2015). Peningkatan Literasi Matematika Mahasiswa Melalui Pembelajaran Inovatif Realistik E-Learning Edmodo Bermuatan Karakter Cerdas Kreatif Mandiri. Jurnal Matematika Kreatif-Inovatif: Kreano. Universitas Negeri Semarang. 6 (1)

Widia. (2014). Peran Mahasiswa dalam Meningkatkan Mutu Pendidikan (online) www.kompasiana.com.

Winarni, Sri. (2013). Integrasi Pendidikan Karakter Dalam Perkuliahan. Yogyakarta: Universitas Negeri Yogyakarta Jurnal Pendidikan Karakter, Tahun III, Nomor 1, Februari 2013 